\title{
OKTATÁSI ÉPÜLETEK KÜLÖNLEGES ÉPÍTÉSZETI IGÉNYEI
}

\section{SPECIAL ARCHITECTURAL REQUIREMENTS OF EDUCATIONAL BUILDINGS}

\author{
Kovács Péter, ${ }^{1}$ Molnár Tamás, ${ }^{2}$ Kósa Balázs ${ }^{3}$ \\ Pécsi Tudományegyetem, Müszaki és Informatikai Kar, Vizuális Ismeretek Tanszék, Pécs, Magyarország \\ ${ }^{1}$ kope.hun@gmail.com \\ ${ }^{2}$ tmolnar@mik.pte.hu \\ ${ }^{3}$ kosa.balazs@mik.pte.hu
}

\begin{abstract}
In the decades elapsed since the construction of the majority of educational buildings in Hungary, there have been various social, economic, and demographic developments that affect the utility of existing infrastructure. These changes present special requirements - those not met by existing, often heritage buildings - setting a challenge to both architects and decision makers. The aim of this study is to analyze the various aspects of these developments and reflect on the extant architectural framework of education, serving as a basis for further investigations on ways architecture can enhance the learning environment.
\end{abstract}

Keywords: built heritage, educational buildings.

\section{Összefoglalás}

A Magyarország oktatási épületállományának megépülte óta eltelt évtizedekben számtalan gazdasági, társadalmi változás ment végbe. E változások új - különleges - igényeket támasztanak, új kihívások elé álítva döntéshozókat és építészeket. E tanulmány célja elemezni ezen változásokat és hatásukat a meglévő épületállomány hasznosítására.

Kulcsszavak: épitett örökség, oktatási épületek, épület-rehabilitáció.

\section{A meglévő épületállomány elemzése}

Magyarország oktatási épület-állományának gerincét a XX. század közepén, második felében létrejött épületek alkotják, kiegészülve a korábbi, ma már az épített örökségünk részét képező és kis számban későbbi, a rendszerváltás utáni építészet eredményeként létrejött iskolaépületekkel. Ennek eredményeképpen olyan infrastruktúráról beszélhetünk, melynek fejlesztése korunkban és a jövőben is kihívás elé állítja az építésztársadalmat. A tanulmány célja számba venni és megvizsgálni az oktatás épített környezetét, illetve a megváltozott igényeket, melyekkel feléjük fordul a társadalom.

A több száz év alatt kialakult állomány nem csak az épületek különbségei által, de azok megoszlása szerint is igen változatos képet mutat. Más-más városok, tájegységek határozottan eltérő képet mutatnak, gazdasági helyzetük, demográfiai történetük következtében. Következésképpen, amennyiben az építész szakma által hasznosítható tanulsággal bíró vizsgálatot szeretnénk folytatni, nem célszerű statisztikai módszerekhez folyamodnunk, mivel a régiók, települések közti különbségek által lehetetlen egy átfogó kép kialakítása.

Célravezetőbb egy tipológia felállítása, melyben a tanulmányban meghatározott szempontok szerint hasonló elemeket tekintjük típusnak, és e típusokra vonatkoztatva végezzük vizsgálatunkat.

A tanulmány először is ezeket a szempontokat tárja föl, melyek egyfelől a hatások, melyek kihatnak az oktatási építészetre, másfelől az elvárások, melyeket a társadalom támaszt az épületek felé. 


\section{Az igények változása és a változást kiváltó hatások}

\subsection{Gazdasági hatások}

Az épületállomány változásaira kiható szempontok közül különösen erősen jelentkezik a gazdasági tényezők hatása. A többi szempont, melyet vizsgálunk, társadalmi igényként jelentkezik, de ezen igények minden esetben valamely gazdasági mechanizmuson átszűrve jelennek meg az építési tevékenységben. E szempontok közé sorolható az oktatásra fordított állami források mennyisége, az iskolák üzemeltetésének centralizálása vagy decentralizálása, a különböző oktatási formák, anyagi támogatottsága.

Itt fontos megjegyeznünk az e mechanizmusok működéséből létrejövő gazdasági egyenlőtlenségeket is, melyek hatása a kisebb társadalmi nyomást élvező oktatási formák, kisebb érdekérvényesítő képességű társadalmi csoportok lakta régiók oktatási infrastruktúrájának minőségén megfigyelhető.

\subsection{Demográfiai hatások}

Új oktatási épületek létrehozásának fő mozgató ereje a népesség változása. A múlt század fejlesztései mögött álló nagymértékű urbanizáció hozta létre a jelenlegi oktatási épületek javát, míg az elmúlt két évtizedben a szuburbanizáció keltett igényt új intézmények, épületek létrehozására. A népességszám változásain felül az adott régió népességének kora, társadalmi, etnikai hovatartozása, ezek változása is szerepet játszhat az oktatási infrastruktúra alakulására.

\subsection{Oktatásmódszertan}

A közoktatásban az oktatás modellje az elmúlt évszázadokban, a protestáns iskolák megjelenése óta nem változott oly mértékben, hogy történeti iskolaépületekben ellehetetlenítse az iskolák működését - az ettől eltérő, alternatív iskolák új intézményként, új épületekkel jelentkeznek. [1] Számos kisebb változás azonban hatással van a korábbi épületek használhatóságára.

Az oktatásmódszertan építészetben legerősebben jelentkező vetülete az osztálylétszámok változásából ered. Bár e tényező gazdasági vetületei által megkötésekbe ütközik, hosszú távú tendenciaként az osztálylétszámok csökkentése figyelhető meg. A tanulók iskolában töltött ideje jellemzően nő, így felmerül az igény a tanulmányi funkciókon kívüli szociális igényekre jobban reflektáló iskolaépítészetre.

\subsection{Szociális igények}

Az előzőekből következően olyan igények építészeti vetülete is megjelenhet oktatási épületeken, melyek kilépnek a szigorúan vett oktatási tér definíciójából. A hallgatók szociális igényeinek teljesebb körü kielégítésén túl teret nyerhet az iskola közösségi szerepe is. Ez jól tetten érhető a szuburbanizáció okán létrejött iskolaépületeken, ahol a meglévő infrastruktúra hiányában még hangsúlyosabban jelenik meg az iskola szerepe a közösség életében.

\section{5. Épületfizikai igények}

Épületfizikai szempontból vizsgálva két fő okból változnak oktatási épületekkel szemben támasztott igényeink. Egyfelől a gazdaságos fenntarthatóság igénye jelentkezik egyre erősebben, más felől pedig az intézmények komfortja, az oktatási tér minősége, használhatósága szempontjából jelennek meg magasabb elvárások.

A felsorolt nehézségeket tetézi a jelenleg zajló klímaváltozás, mely az ősztől tavaszig tartó használatra tervezett épületek esetében is jobb árnyékolási, szellőzési, esetleg hűtési megoldásokat kíván.

\subsection{Akadálymentesség}

Társadalmi szinten egyre nő az igény, hogy oktatási intézményeink befogadóbbak legyenek a fogyatékossággal élők felé. Ennek megvalósítása fizikai és gazdasági akadályokba ütközik a meglévő épületek esetében. A szűk értelemben vett akadálymentesítésen kívül a kortárs építészet érzékenyebben reagál a gyermekek fizikai, érzelmi, szellemi adottságaira, befogadóbb tereket hozva létre. Hosszú távon ezek az integrált iskolaépületek társadalmi-gazdasági szempontból is kívánatosak, csökkentve az igényt specializált intézmények üzemeltetésére.

\section{Tipológiai elemzés}

\subsection{Történeti iskolaépületek}

Elemzésünk szempontrendszere szerint egy típusba sorolhatjuk a modernista építészet térhódítása előtt épült, mára gyakran műemléki védettséget élvező épületeket. Átalakításuknak további akadálya a történelmi városszövetben való elhelyezkedésük, szoros beékelődésük.

Üzemeltetésük gazdaságtalanságát ellensúlyozza a történelmi campus eszmei értéke, az intézmény múltjának megjelenítése. Így bár fejlesz- 
tésük nehézségekbe ütközik, ritka esetben lép fel szándék a történelmi épületek szanálására. A felmerülő akadályok ellenére a hazai kortárs építészet több példát is felmutathat eme épületek invenciózus hasznosítására.

\subsection{Modernista iskolaépítészet}

Magyarországon a modernista iskolaépítészet legtöbb példája a II. világháború és a rendszerváltás közötti időszakból származik. Az erős urbanizáció nyomán létrejött iskolaépítési hullám jellegzetes eleme a típusterv alapján épült iskola - ennek ellenére a korszak bővelkedett a fontos építészeti újításokban, és sokszor az elterjedt típustervek is egy sikeres egyedi terv ismétlései. [2] A korábbiakhoz képest előrelépés történt az oktatási épületek oktatási és szociális tereinek formálásában, a természetes világítás és szellőzés használatában - többek között ekkor jelent meg a „zsibongó”, mint a korábbi előcsarnoktól funkcionálisan elkülönülő, közösségi célú tér, elsők között Kismarty-Lechner Kamill munkássága nyomán. (1. ábra)

A kedvezőtlenebb társadalmi megítélésnek köszönhetően ezen épületek utóéletét gyakrabban jellemzik az átgondolatlan, építészeti koncepciót nélkülöző átalakítások, felújítások, holott kortárs szemlélettel is minőségi épületekről beszélhetünk, melyek felújítása a jellemző épületfizikai, akadálymentességi problémák megoldásán felül akár a kortárs elvágásoknak megfelelő újraértelmezésre adhat lehetőséget - példa erre Csontos Györgyi Újvárostéri Iskolája. [3]

\subsection{Szocialista-realista iskolaépítészet}

E rövid életű irányzatnak, a nehéziparral összefüggő városépítési hullám hatására, számos példájával találkozhatunk. Mind társadalmi, mind

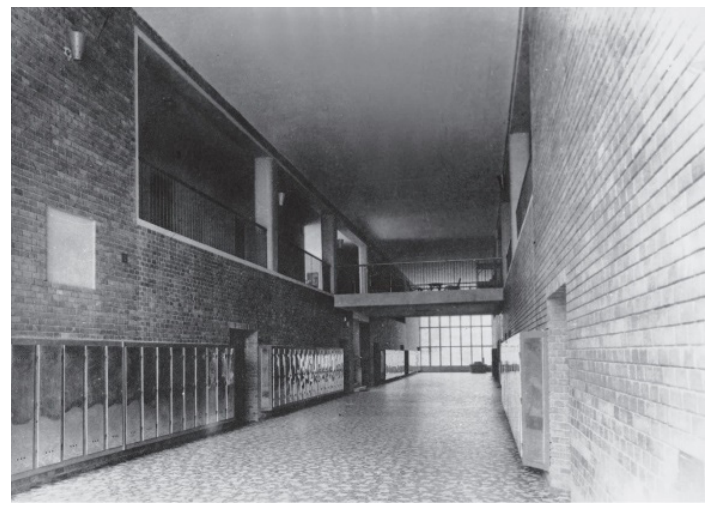

1. ábra. Kismarty-Lechner Kamill: Budapest, Sodronyos út 28., általános iskola. 1955-1958. [2] szakmai megítélése negatív - fontos azonban figyelembe vennünk urbanisztikai kontextusban képviselt értékeit, melyeket jól példáz a lakókörnyezet és a különböző szintű oktatási épületek kapcsolatának funkcionális és városépítészeti szempontokat ötvöző átgondoltsága.

\subsection{Oktatási épületek a 90-es évektől}

A rendszerváltás utáni új oktatási intézmények, épületek létrejöttét már jellemzően a szuburbanizáció generálta. A hazai építészet bővelkedik olyan példákban, melyek kreatívan reagálnak az ebből fakadó kihívásokra, az iskola változó szerepére a közösségi életben. A minőségi kortárs példák további jellemzője a gazdaságosság kérdésének helyi szinten való átgondolt kezelése - ezeket jól szemlélteti Getto Tamás pellérdi iskolaépülete. [4]

\subsection{Oktatási épületek adaptációi}

A korábban felhozott példák mellett előfordul, hogy oktatási intézmény kényszerül müködni más célra vagy más jellegű oktatás céljából létrehozott épületekben, jellemzően makrogazdasági indokokból, vagy önálló fenntartású, alapítványi vagy magániskolák esetében az intézmény saját gazdasági helyzetéből fakadóan. Amennyiben az alkalmazott oktatási modell nem gyökeresen eltérő, ezen épületek továbbra is működőképesek, ám sok esetben nem tudják kielégíteni az adott intézmény sajátságos igényeit.

A kérdéskör másik vetületét az oktatás által hátrahagyott épületek jelentik, melyek adaptációja más funkcióra szinte lehetetlen, s melyek sorsa ezért gyakran az enyészet.

\subsection{Különleges oktatási intézmények épületei}

Ide sorolhatók a különleges pedagógiai megközelítéssel oktató intézmények, a fogyatékkal élőket kiszolgáló iskolák, és azok, melyek társadalmi okokból hátrányos helyzetű tanulóknak nyújtanak segítséget. Közös pont ezekben, hogy az eltérő pedagógiai módszereket, a tanulók különleges igényeit az ezeket alapul vevő, adott igényekre szabott építészeti program, terek tudják ideális minőségben kiszolgálni. [5] Szerencsés esetben ez meg is valósul, és olyan oktatási épületek jönnek létre, melyek - azon felül, hogy az adott intézményt megfelelően szolgálják - a kevésbé speciális oktatási intézmények tervezésénél is figyelembe vehető építészeti tanulságokat mutatnak föl, tervezőik érzékenysége, a kívánalmak feltárásának alapossága által. Különösen igaz ez az alternatív iskolákra, ahol lehetőség nyílik akár piaci alapon olyan forrásokat felmutatni, ame- 
lyek lehetővé teszik a közoktatásban megszokottnál magasabb színvonalú épületek létrejöttét.

Ugyanakkor, mivel ezek az intézmények egyediségük révén nehezen illeszthetők az oktatás támogatási rendszerébe - az adott oktatási forma társadalmi támogatottságának hiánya, esetleg a célcsoport érdekérvényesítő képességének gyengesége okán - előfordulnak az előző pontban ismertetett kényszermegoldások.

\section{Következtetések}

A leírtakból és a felhozott pozitív példákból következik, hogy Magyarország oktatási épületállományának jelentős része a megfelelő építészeti eszközökkel hosszú távon is alkalmassá tehető az oktatás jelen és eljövendő kívánalmainak kielégítésére.

A meglévő épületek hasznosításánál jelenleg jellemző, hogy az épületállomány makrogazdasági érdekek mentén vezérelt kezelése és így az építész szakma megfelelő bevonása hiányában adott épületek, intézmények esetén szakmai koncepciót nélkülöző átalakításokhoz, fejlesztésekhez vezethet.
Az épületállományon az anyagi források egyenlőtlen megoszlásának lenyomata figyelhető meg. E kérdés oka és megoldása társadalmi-gazdasági kérdéskörbe tartozik, ugyanakkor hatással bír az építészet lehetőségeire.

\section{Köszönetnyilvánítás}

Az Emberi Erőforrások Minisztériuma ÚNKP-18-3.-I. kódszámú Új Nemzeti Kiválóság programjának támogatásával készült

\section{Szakirodalmi hivatkozások}

[1] Cságoly F.: Középületek. TERC Kft., Budapest, 2004. 65-83.

[2] Lantos E.: 1945 Utáni iskolatervezés Magyarországon. Típustervek és egyedi épületek. Müvészettörténeti Értesítő, 63/2. (2014) 373-396.

[3] MIXA Stúdió. Ódzd - Újvárostéri iskola. (letöltve: 2019 feb.15.)

https://www.mixastudio.hu/ujvarosteri-iskola/

[4] BME. Általános Iskola - Pellérd. (letöltve: 2019. feb. 15.).

http://hazai.kozep.bme.hu/hu/altalanos-iskola-pellerd/

[5] Sanda I. D.: A reformpedagógiai irányzatok iskolaépítési törekvései. Iskolakultúra, 18/9-10. (2008) 129-142. 